\title{
A Meta-Analysis of Risk Factors for Post-Traumatic Stress Disorder (PTSD) in Adults and Children after Earthquakes
}

\author{
Bihan Tang ${ }^{1,+}$, Qiangyu Deng ${ }^{1,+}$, Deborah Glik ${ }^{2,+}$, Junqiang Dong ${ }^{1}$ and Lulu Zhang ${ }^{1, *}$ (10 \\ 1 Department of Health Service, College of Health Service, Second Military Medical University, \\ Shanghai 200433, China; mangotangbihan@126.com (B.T.); smmudqy@163.com (Q.D.); \\ DJQdxyz@163.com (J.D.) \\ 2 Department of Community Health Sciences, Fielding School of Public Health, University of California, \\ Los Angeles, CA 90095, USA; dglik@ucla.edu \\ * Correspondence: zllrmit@163.com; Tel.: +86-21-8187-1421 \\ $\dagger$ These authors contributed equally to this work.
}

Received: 27 August 2017; Accepted: 7 November 2017; Published: 8 December 2017

\begin{abstract}
PTSD is considered the most common negative psychological reactions among survivors following an earthquake. The present study sought to find out the determinants of PTSD in earthquake survivors using a systematic meta-analysis. Four electronic databases (PubMed, Embase, Web of Science, and PsycInfo) were used to search for observational studies about PTSD following earthquakes. The literature search, study selection, and data extraction were conducted independently by two authors. 52 articles were included in the study. Summary estimates, subgroup analysis, and publication bias tests were performed on the data. The prevalence of PTSD after earthquakes ranged from $4.10 \%$ to $67.07 \%$ in adults and from $2.50 \%$ to $60.00 \%$ in children. For adults, the significant predictors were being female, low education level or socio-economic status, prior trauma; being trapped, experiencing fear, injury, or bereavement during the disaster. For children, the significant predictors were being older age, high education level; being trapped, experiencing fear, injury, or bereavement, witnessing injury/death during the earthquakes. Our study provides implications for the understanding of risk factors for PTSD among earthquake survivors. Post-disaster mental health recovery programs that include early identification, on-going monitoring, and sustained psychosocial support are needed for earthquake survivors.
\end{abstract}

Keywords: PTSD; risk factors; children; adults; earthquakes

\section{Introduction}

Earthquakes have the greatest destructive effect among all natural disasters [1], as they cause not only physical impairments, but also psychological stresses among victims. Over the past several decades, earthquakes have drawn attention for their frequent occurrence and massive destruction [2].

Post-traumatic stress disorder (PTSD) refers to a delayed but lasting psychological stress disorder caused by exposure to trauma, and it is considered the most common negative psychological reactions among survivors following an earthquake [3]. To have PTSD according to the Diagnostic and Statistical Manual of Mental Disorders 5th Edition (DSM-V), a person must first experience a life threatening traumatic event, an event outside the realm of daily human existence that evokes fear, helplessness, and/or horror [4]. These include a persistent re-experiencing of the event, a persistent avoidance of stimuli associated with the event, and the general numbing of responses to stimuli, as well as persistent symptoms that indicate emotional arousal or stress response [2,5]. Symptoms must last at least for 1 month and cause significant impairment in functioning [6]. 
PTSD was first included in the third edition of the Diagnostic and Statistical Manual of Mental Disorders (DSM-III) by American Psychiatric Association in 1980, and it continued to be listed in subsequent editions, that is, DSM-III-Revised (DSM-III-R), DSM-IV, DSM-IV-text revision (DSM-IV-TR), and DSM-V [4]. Posttraumatic stress disorder differs from other anxiety disorders in that the former is caused by the experience of a traumatic event [7]. It is also necessary for us to distinguish acute stress disorder (ASD) from PTSD. The primary difference between ASD and PTSD is the former's emphasis on dissociative reactions to the trauma [8]. The requisite symptoms of ASD include re-experiencing the event, marked avoidance, marked anxiety or increased arousal, and evidence of significant distress or impairment. However, ASD only lasts for 2 days to 4 weeks, after which, if symptoms persist, a diagnosis of PTSD should be considered [8].

There are great variations in rates of PTSD currently reported in the wake of earthquakes. For example, 6 and 12 months after the Wenchuan earthquake in China, the prevalence rates were $11.2 \%$ and $13.4 \%$, respectively, among the children in the town of Qushan, in Beichuan County [9]. Another study that focused on the adult population aged over 18 years was conducted 30 months after Pakistan's 2005 earthquake, and it estimated the prevalence of PTSD to be as high as 41.3\% [2]. Furthermore, the prevalence of PTSD was $24.6 \%$ among the survivors in the Nazon area of Port-au-Prince, 2 to 3.5 months after the 2010 Haiti earthquake [10]. Besides the different prevalance of PTSD among earthquake survivors, their predictors were also not consistent. For example, some studies found that being old was a risk factor for PTSD among adult earthquake survivors while some studies made the opposite conclusions [11-14]. The same phenomenon existed in other factors, such as marital status, injured as a result of earthquake and so on [2,15-17]. Variations in the prevalence and predictors of PTSD have been noted and attributed to differences in study measurements and time of assessment, as well as differences in age, gender, disease history, and cultural background of the samples, and so on [18]. As there is no single dominant determinant that predicts PTSD after an earthquake, it is important to study the risk factors involved.

The onset of PTSD has been studied for more than 20 years and several meta-analyses have been carried out on risk factors for PTSD in different populations. For example, Ozer et al. [19] conducted a meta-analysis on seven separate predictors from 68 studies for PTSD among adults. Trickey et al. estimated the population effect sizes of 25 potential risk factors for PTSD in children and adolescents aged 6-18 years across 64 studies $(n=32,238)$ [20]. These have focused on different kinds of populations such as trauma-exposed adults [21], rescue workers [22], HIV-positive women [23], refugees and internally displaced persons [24], military personnel, and veterans [25]. To date, however, there has been no meta-analysis of risk factors for PTSD in populations specifically affected by earthquakes.

While not all people who have suffered a qualifying trauma go on to develop a disorder, investigators have documented basic characteristics, trauma-related, and post-trauma risk factors that may increase vulnerability to a PTSD [26]. Similarly, risk factors for PTSD among earthquake survivors can also be divided into these three categories but quite different in detail. Earthquake survivors have their specific factors which resulted in PTSD symptoms, such as earthquake-related experience (i.e., trapped in an earthquake, injured by the earthquake) and post-earthquake characteristics (i.e., house damage and property loss as a result of earthquakes). Although there are many separate articles focusing on predictors of PTSD among earthquake survivors, their results are not always consistent. It is essential to make a meta-analysis to elaborate on the determinants of PTSD on earthquake survivors.

Considering the need to better understand survivors in face of an earthquake, and to assist them more effectively, this study aimed to identify the determinants of PTSD in earthquake survivors using a systematic meta-analysis of observational studies. In all, our study can add essential information to the better preparedness and implementation of tailored treatments in earthquake-stricken areas to reduce symptoms and aid post-disaster recovery. 


\section{Methods}

\subsection{Search Strategy}

Observational studies (case-control, cross-sectional, and cohort studies) on risk factors for PTSD among earthquake survivors published in English between 1980 (the year PTSD was first included in the Diagnostic and Statistical Manual of Mental Disorders, DSM) and April 2016 were included in this meta-analysis. The following four psychological and medical literature databases were searched: PubMed, Embase, PsycInfo, and Web of Science. Search terms entered into the literature databases included combinations of the following: PTSD or post-traumatic stress disorder; earthquake(s); and risk, predictor, or prediction. A predictor or risk factor was operationally defined as any variable examined as a potential contributor to variability in PTSD symptom levels or diagnostic status. In addition, a manual search of references cited in all relevant original and review articles was conducted. For any full texts not available, we attempted to obtain information from the authors by email. This literature search yielded 886 published articles, which were then reviewed for inclusion in the meta-analysis using various inclusion and exclusion criteria.

\subsection{Inclusion and Exclusion Criteria}

To be eligible for inclusion in the meta-analysis, studies had to meet the following criteria: (a) was an epidemiological investigation on risk factors for PTSD among earthquake survivors; (b) reported the odds ratios (ORs) or relative risks (RRs) and corresponding 95\% confidence intervals (CIs) for risk factors in the development of PTSD in the study population; (c) included PTSD risk factors selected; and (d) defined PTSD with validated scales. The term "validated scale" referred to generalized PTSD scales that have been verified to exhibit good reliability and validity, such as DSM-IV, the civilian version of the PTSD Checklist (PCL), Impact of event scale-Revised (IES-R), Davidson Trauma Scale (DTS), and so on. Articles were excluded on any of the following grounds: (a) the study measured only the acute trauma response (e.g., Acute Stress Disorder or PTSD measured before one month post-trauma) rather than PTSD, which, according to the DSM-IV-TR, can be diagnosed only after one month [4]; (b) the study used only a categorical measure of PTSD-in other words, they included individuals meeting full diagnostic criteria and those with less severe post-traumatic symptoms or partial PTSD (e.g., "subsyndromal PTSD") in the same comparison group, and contrasted them with a group exposed to the same event, but without PTSD; (c) the study population consisted entirely of individuals already suffering from PTSD or from a specific comorbid psychiatric disorder (e.g., depression, attention deficit hyperactivity disorder, substance abuse, learning disabilities) or having committed a violent offense, which would limit the generalizability of the results; (d) the study did not specifically assess DSM-defined PTSD symptoms (e.g., studies that reported only general symptoms); (e) the study contained insufficient data to calculate univariate effect sizes, and such data could not be obtained from the study author; (f) the article was a review, did not present new data, or only presented qualitative analyses; $(\mathrm{g})$ the primary aim of the study was to investigate treatment efficacy; and (h) the study used a single-case design. Studies in which most of the study sample was less than 18 years old were classified as child studies; otherwise, they were classified as adult studies. Finally, if more than one article reported data from the same sample, then the most recent and complete article was included in our meta-analysis. All eligible studies were carefully reviewed by two authors (Bihan Tang and Qiangyu Deng) to ensure decision-rule consistency, with 100\% agreement.

\subsection{Data Extraction and Quality Assessment}

Data extraction was performed by two investigators (Bihan Tang and Qiangyu Deng) independently. The following information was extracted from each eligible study: first author's surname, year of publication, earthquake location, earthquake year, magnitude, population type, study design, PTSD diagnosis, sample size, PTSD prevalence, research time after the earthquake, gender of the participants, estimated effect size (OR/RR), corresponding 95\% CI, and covariates adjusted 
for in the statistical analysis. If a study reported several multivariable-adjusted effect estimates, we selected the estimate that adjusted for the most potential confounding variables, when considering the major risk factors for PTSD among earthquake survivors. Quality assessments of each study identified were conducted independently by two investigators (Bihan Tang and Qiangyu Deng) using an 11-item instrument recommended by the Agency for Healthcare Research and Quality (AHRQ) for cross-sectional studies [27] and the 9-star Newcastle-Ottawa Scale (NOS) for cohort and case-control studies [28]. Studies with eight stars or more on the AHRQ and NOS were considered to be of high quality. Where the two raters' quality assessments differed, the original articles were re-examined along with two more co-authors, until a final quality rating was agreed upon.

\subsection{Classification of Risk Factors}

According to previously published studies, risk factors for PTSD among children and adults after earthquakes were divided into three categories: basic characteristics (including age, gender, education, marital status, religious beliefs, ethnicity, prior trauma, socio-economic status and disease history), trauma characteristics (including being trapped; experiencing fear, injury, or bereavement, e.g., losing close friends or family members; or witnessing injury/death as a result of the earthquakes), and post-trauma characteristics (including amount of social support, employment, loss of property, house damage and involved in rescue) [29].

\subsection{Statistical Analysis}

We examined risk factors for PTSD in earthquake survivors based on the ORs and 95\% CIs reported in each study. A random-effects model [30] which assumes that the real potential effect varies among included studies, was used to estimate the pooled RRs with $95 \%$ CIs. Heterogeneity between studies was evaluated using the $\chi^{2}$ test and $I^{2}$ statistic, with $p$ values lower than 0.05 indicating heterogeneity and higher $I^{2}$ values indicating greater variability among trials than that which would be expected by chance alone (range: $0-100 \%$ ) [31]. The thresholds of $25 \%$ and $50 \%$ in $I^{2}$ test indicated low, moderate, and high heterogeneity, respectively. The probability of publication bias was assessed using Egger's regression test, and values of $p<0.05$ were considered statistically publication bias [32]. If publication bias was present, we tried to evaluate the effect of the publication bias using the trim and fill method. We separated out data collected on children from adults as research suggests the presence of somewhat different factors [29]. To examine the possible effects of these variables on the study results, we conducted analyses for the following subgroups analyses: high-quality studies (with a score of 8 or more), survivors from high magnitude earthquakes (magnitude of above 7). Having a long period between the research and the earthquake raises the possibility that participants may have been exposed to subsequent traumatic events in addition to the earthquake, which may confound the interpretation of the results. Therefore, we also excluded studies that were implemented a long time after the onset of the disaster ( $>6$ months). When risk factors were for multi-categorical variables (e.g., age, educational level, fear, house damage, loss of property, and social support), we used the ORs of the highest versus the lowest category. If risk factors were continuous variables (such as age in some studies), they were excluded to avoid inaccuracy because it is not appropriate to combine the ORs from continuous and segmental data. Stata Version 12.0 software (Stata Corp., College Station, TX, USA) was used for all analyses and all statistical tests were two-tailed. Values of $p<0.05$ were considered statistically significant.

\section{Results}

\subsection{Characteristics of Studies}

Figure 1 shows the complete selection process. A total of 1798 records indexed until April 2016 were retrieved using our search strategy, and 744 records were discarded owing to duplication. We excluded another 957 articles after reading the titles and abstracts, and retained 
the remaining 97 articles for further evaluation by reading the full texts. Finally, we selected 52 full-text articles on risk factors for earthquake-related PTSD among survivors for our meta-analysis (Figure 1) [2,3,6,10-16,26,33-72]. Furthermore, 37 studies investigated the association between risk factors and PTSD in adult survivors of earthquakes, totaling 11,963 PTSD cases out of 56,722 participants. 15 studies investigated the association between risk factors and PTSD in child survivors of earthquakes, totaling 3461 PTSD cases out of 22,931 participants. Table A1 shows the general characteristics of the 52 studies included in the analysis. Sample sizes from individual studies ranged from 105 to 14,207 .

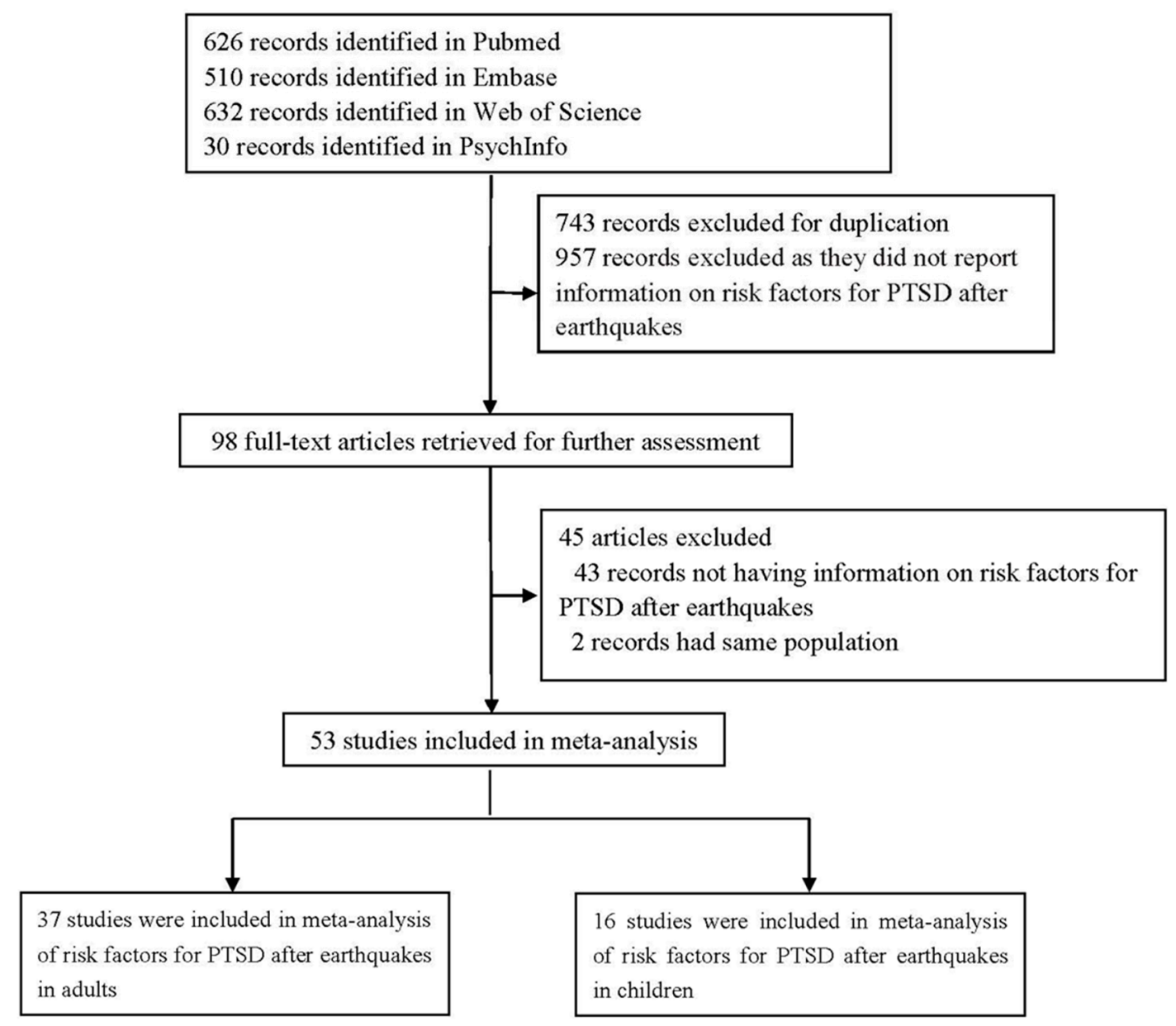

Figure 1. Search results and excluded/included studies.

\subsection{Risk Factors for PTSD in Adults}

The prevalence of PTSD in adults after earthquakes ranged from $4.10 \%$ to $67.07 \%$. The risk factors for earthquake-related PTSD among adult survivors have been presented in Table A2 and Figure 2. Regarding the basic characteristics of survivors, we found that being older, being female, having a high-level education, low socio-economic status, and prior trauma were significantly associated with PTSD after earthquakes, with pooled ORs of 1.17 (95\% CI, 1.08-1.27), 1.85 (95\% CI, 1.69-2.02), 0.81 (95\% CI, 0.75-0.87), 1.74 (95\% CI, 1.24-2.45) and 1.63 (95\% CI, 1.10-2.41), respectively. However, heterogeneity was found for age $\left(I^{2}=73.2 \%, p<0.001\right)$, gender $\left(I^{2}=51.1 \%, p<0.001\right)$, education $\left(I^{2}=33.3 \%, p=0.041\right)$, marriage $\left(I^{2}=79.6 \%, p<0.001\right)$, religion $\left(I^{2}=72.0 \%, p=0.006\right)$, ethnicity $\left(I^{2}=82.9 \%, p<0.001\right)$, socio-economic status $\left(I^{2}=89.0 \%, p<0.001\right)$, and prior trauma $\left(I^{2}=55.3 \%\right.$, $p=0.135)$. In addition, we found a publication bias for age (Egger's test $p=0.013$ ). Thus, after adjusting for publication bias, the OR for age was 1.05 (95\% CI, 0.96-1.15), which was no longer a significant risk 
factor. The subgroup analyses showed inconsistencies in the results for age, socio-economic status and ethnicity, which should be interpreted with caution because of potential bias.

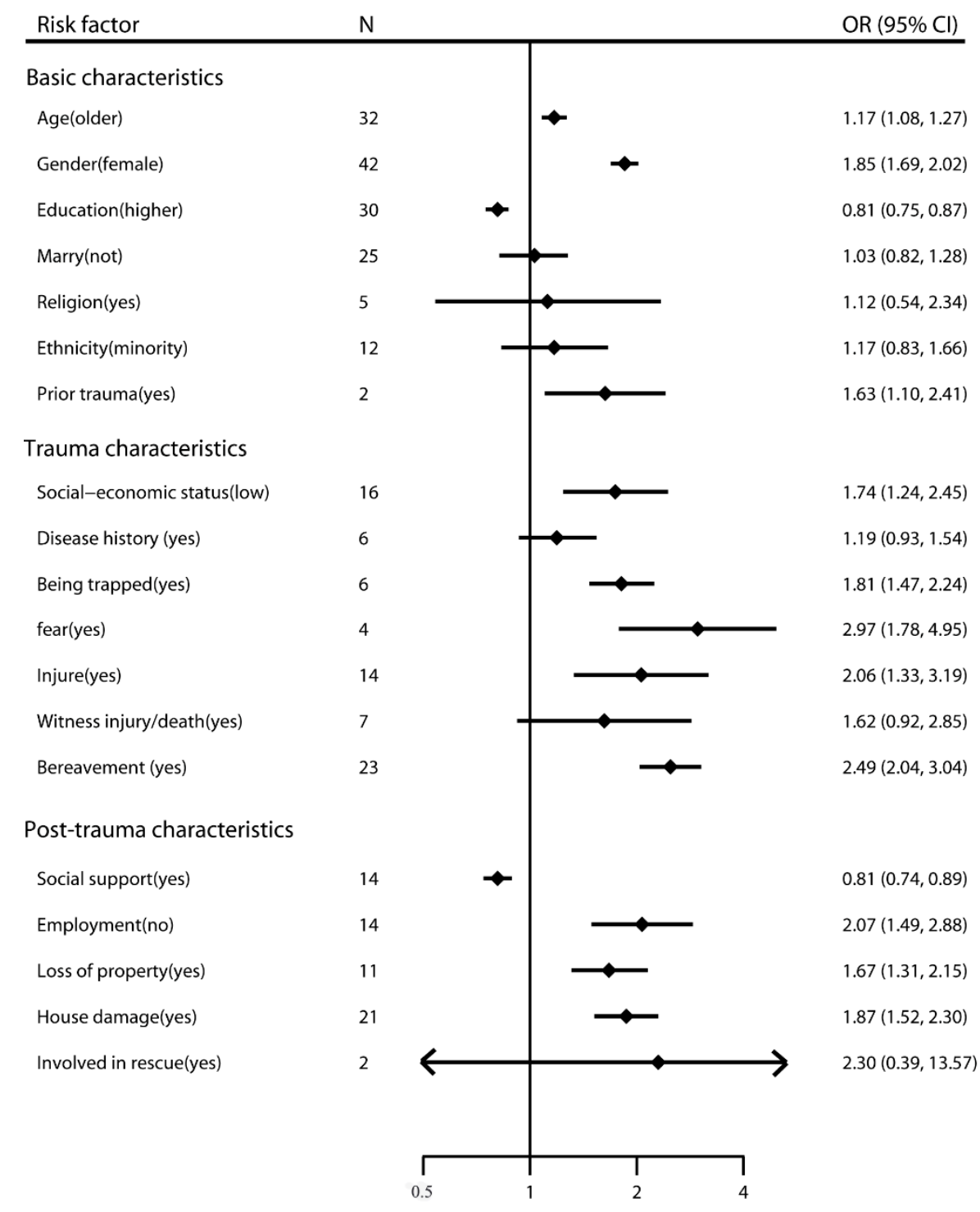

Figure 2. Risk factors for PTSD after earthquake in adults.

With regard to the trauma characteristics of survivors, people who experienced being trapped, or those who experienced fear, injury, or bereavement during a natural disaster were more likely to suffer from PTSD, with pooled ORs of 1.81 (95\% CI, 1.47-2.24), 2.97 (95\% CI, 1.78-4.95), 2.06 (95\% CI, 1.33-3.19), and 2.49 (95\% CI, 2.04-3.04), respectively. Heterogeneity was found for the characteristics of experiencing fear $\left(I^{2}=92.9 \%, p<0.001\right)$, injury $\left(I^{2}=90.0 \%, p<0.001\right)$, witnessing injury/death $\left(I^{2}=90.5 \%, p=0.041\right)$, and bereavement $\left(I^{2}=70.8 \%, p<0.001\right)$. The results were consistent according to the subgroup analyses, except for injury.

Finally, analysis of the post-trauma characteristics of survivors showed that social support (OR 0.81, 95\% CI, 0.74-0.89), employment (OR 2.07, 95\% CI, 1.49-2.88), loss of property (OR 1.67, 95\% CI, 1.31-2.15), and house damage (OR 1.87, 95\% CI, 1.52-2.30) were related to PTSD. However, heterogeneity was observed with reference to social support $\left(I^{2}=94.7 \%, p<0.001\right)$, employment $\left(I^{2}=85.5 \%, p<0.001\right)$, loss of property $\left(I^{2}=60.2 \%, p=0.005\right)$, house damage $\left(I^{2}=60.6 \%, p<0.001\right)$, and involvement in rescue $\left(I^{2}=98.1 \%, p<0.001\right)$, suggesting that the findings on these variables 
showed inconsistencies. The subgroup analyses showed inconsistencies in the results for social support and involvement in rescue, which should be interpreted with caution because of potential bias. We also found a publication bias for loss of property (Egger's test $p=0.005)$. Thus, after adjusting for publication bias, the OR was 1.30 (95\% CI, 1.01-1.68).

\subsection{Risk Factors for PTSD in Children}

The prevalence of PTSD in children after earthquakes ranged from $2.50 \%$ to $60.00 \%$. The risk factors for PTSD after earthquakes in children have been presented in Table A3 and Figure 3. Regarding the basic characteristics of survivors, the pooled analysis showed that age (OR 1.34, 95\% CI, 1.12-1.61), gender (OR 1.45, 95\% CI, 1.31-1.60), and educational level (OR 1.57, 95\% CI, 1.11-2.21) were associated with risk of PTSD. However, heterogeneity was found for educational level $\left(I^{2}=77.7 \%, p<0.001\right)$. Furthermore, we found inconsistencies in educational level in the subgroup analyses.

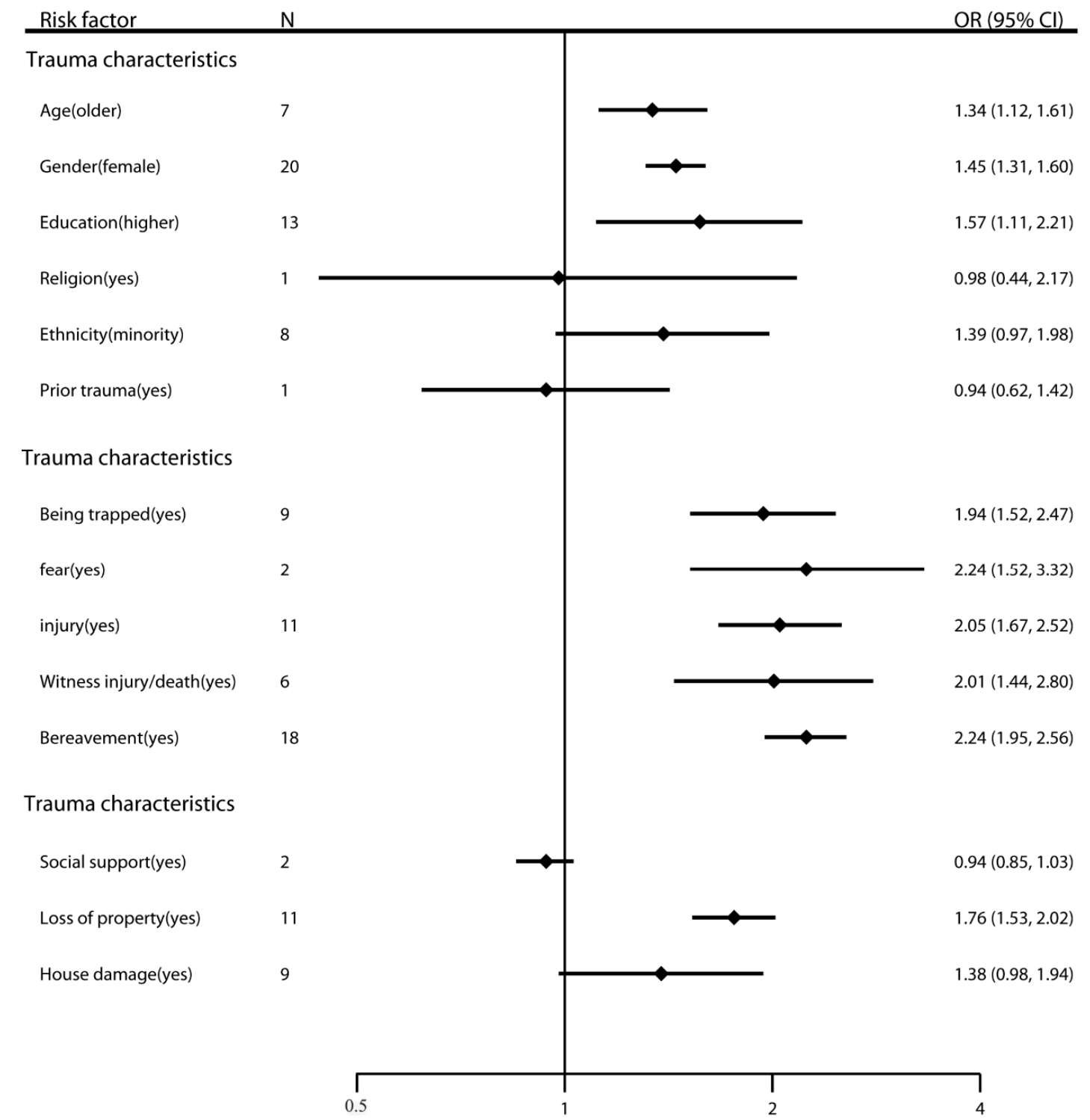

Figure 3. Risk factors for PTSD after earthquake in children.

The initial analysis of the trauma characteristics of survivors (i.e., before excluding low-quality and unadjusted studies) revealed that all five factors were associated with risk of PTSD; the pooled ORs were 1.94 (95\% CI, 1.52-2.47) for being trapped, 2.24 (95\% CI, 1.52-3.32) for experiencing fear, 
2.05 (95\% CI, 1.67-2.52) for experiencing injury, 2.01 (95\% CI, 1.44-2.80) for witnessing injury/death, and 2.24 (95\% CI, 1.95-2.56) for bereavement. However, heterogeneity was found for witnessing injury / death $\left(I^{2}=64.9 \%, p=0.014\right)$, which also had a publication bias. After adjusting for publication bias, the OR for witnessing injury/death was 1.54 (95\% CI, 1.12-2.13). Besides, the subgroup analyses showed inconsistencies in the results for experiencing fear, which should be interpreted with caution because of potential bias.

Finally, with regard to the post-trauma characteristics of survivors, only one factor (i.e., loss of property) was found to be a risk factor for the onset of PTSD (OR 1.76, 95\% CI, 1.53-2.02). Heterogeneity was found for house damage $\left(I^{2}=55.1 \%, p=0.023\right)$.

\section{Discussion}

To the best of our knowledge, this is the first meta-analysis focusing on the risk factors for PTSD in populations specifically affected by earthquakes. Our synthesis of the relevant published English-language articles provided strong evidence for risk factors of PTSD among earthquake survivors. This study analyzed 52 published observational studies (1 case-control, 1 cohort, and 50 cross-sectional studies, including a total of 79,653 people). A total of 19 risk factors of PTSD in the survivors of earthquakes were explored and categorized into the following three types: basic characteristics, trauma characteristics, and post-trauma characteristics. Fourteen (73.68\%) risk factors were investigated in ten or more studies. Although an increasing number of researchers have been studying earthquake-related PTSD in the past decades, only a limited number of variables have been routinely investigated.

With regard to basic characteristics, one important risk factor for the development of PTSD in both children and adults was gender. This is consistent with a report of the WHO that also showed gender differences in the ability to cope with stress after disasters [73]. Genetic and biological factors are expected to play some role in these differences. For example, women are thought to be more sensitive to stress hormones, more sensitive to threats, less likely to use effective coping strategies, and more likely to interpret disasters more negatively than men are [17]. In addition, the traditional role of females in the society exposes them to greater stress, which may also render them less capable of changing their stressful environment. Gender was a common risk factor both in children and in adults. It is possible that the gender role socialization that begins at an early age may play a role as boys learn to suppressor deny psychological symptoms, whereas girls learn to reflect their feelings more and become more emotionally expressive [74]. Our results also suggested that older child survivors after earthquakes were more likely to develop PTSD than younger ones were. This may reflect the universal characteristics of child PTSD distribution after earthquakes, and further research is needed to investigate the psychosocial and biological mechanisms of older female children who are at high risk for PTSD after earthquakes. Adults with a low educational level and socio-economic status were at high risk of PTSD after earthquakes. For adults, level of education indirectly influences economic resources, social status, social networks, and health behavior [60]. Thus, those with a higher level of education and socio-economic status might use better coping methods because of their greater social and economic resources, and ultimately would be less impacted by earthquakes, which in turn reduces the prevalence of PTSD. However, as for children, high educational level indicated a higher risk of PTSD. Senior students might experience greater academic stress due to their heavier study load than junior students would, which could result in higher PTSD prevalence. Prior exposure to trauma was another risk factor of PTSD among adult survivors, which can be partly explained by the idea that the accumulation of violent traumatic events throughout the life course could increase the risk of mental disorders [10]. As for children, prior exposure to trauma was not a significant risk factor, since children may be too young to accumulate enough violent traumatic events to affect their psychological health status in an obvious sense. 
In terms of trauma characteristics, children and adults shared the following four risk factors: experience of being trapped, fear, injury, and bereavement. Being trapped is without a doubt an extremely traumatic experience. Therefore, the persistence of PTSD symptoms in this group seemed to be related to pervasive trauma reminders that were embedded in the circumstances after the earthquake. Reminders such as debris, destroyed buildings, and casualties served as ongoing reminders of the earthquake-related trauma and continually reactivated the symptoms [6]. Given that PTSD is a fear-based disorder, fear during the earthquake was a strong predictor of PTSD. Exposure-based treatments have proven to be highly effective in PTSD, and psychological interventions targeting fear in earthquake survivors are expected to lead to a reduction in traumatic stress symptoms [68]. The link between being injured and PTSD is possibly related to the severity of the injuries, which are often so severe after an earthquake that they result in amputation and disability [26]. The onset of disability is likely to reduce health-related quality of life in these people, and this loss of quality of life might lead to PTSD. Besides, people who were injured were always at high risk, reflecting both their high level of exposure to mortal danger and the added persistent reminder and additional stress accompanying an ongoing injury and the necessary rehabilitation associated with it [11]. In our study, most articles concluded that injury was a risk factor of PTSD and only two articles considered injury as a protective factor of PTSD. This phenomenon may be partly explained by study bias, and partly by the possibility that those who were injured often got more social support than those who were not injured, which made them less susceptible to PTSD. Bereavement removes part of the support resources from close relationships at a time of intense need, compounding the psychological stress and predisposing individuals to PTSD. This highlighted that the bereaved survivors should receive psychological screening and indicated interventions by priority. Witnessing injury or death was another risk factor of PTSD among child survivors. Children are more sensitive to traumatic images compared to adults. For adults, accumulation of life experience makes them more adaptable and calm when exposed to dramatic scenes [26]. However, the horrible memory, in which children witnessed people being crushed and wounded by collapsed and destroyed buildings, is often re-experienced several months or even several years later in their lives [62]. Furthermore, being direct witnesses of traumatic scenes might exert adverse effects on children's cognitive and emotional functioning.

With regard to post-trauma characteristics, loss of property was associated with a higher risk of PTSD both in children and in adults. With loss of property, children and their family members might face persistent financial problems and difficulties with living arrangements. Children tend to worry about the family's situation and the future [75]. As for adults, the risk factors for the onset of PTSD also included house damage, unemployment, social support, and socio-economic status. It is reasonable to assume that the extent of dwelling destruction and unemployment due to an earthquake could reflect the strength of trauma to some degree. Moreover, unemployment and severe house damage resulted in people becoming unable to care for their families to the same extent that they could before the disaster, indicating that the implementation of social interventions such as income-generating activities and facilitating early return to work are critical. When facing forces of earthquakes, social relationships as well as material and spiritual encouragement from families and friends positively offset the negative effects of trauma. Social support could be helpful in PTSD intervention and prevention measures, and substantial social support should be encouraged to be offered by the government and other aid organizations.

It is important to note that our study had some limitations. This meta-analysis only included observational studies; most data were based on self-report measures, which can be prone to biases in sample selection, recall, and information evaluation, as well as confounding biases. There was also significant heterogeneity among the studies due to differences in sampling, design, measurement, and statistical analysis. This is not uncommon in reviews of observational studies. Furthermore, the initial search was restricted to publications in English language, and it is not known to what extent this limitation may have influenced the findings. Moreover, many of the variables included in the analyses were only examined in a small proportion of studies, which limits the conclusions that can be drawn 
about these risk factors. However, the present study does also help to highlight areas that warrant further investigations.

\section{Conclusions}

Despite the limitations outlined above, our study provides some implications for the theoretical understanding of PTSD among earthquake survivors. Firstly, as earthquakes occur increasingly frequently all over the world, these data help psychiatrists to identify the vulnerable population more effectively, which in turn would help them administer treatment in time. Secondly, our results suggest that PTSD in disaster survivors may persist over time; hence, there is a need to introduce feasible interventions at the community or primary mental health care level. The results may also provide clear intervention directions for government policy makers to establish programs to improve assessments, prevention efforts, and interventions for at-risk groups. In addition, these results can help clinicians understand the relevant risk factors and provide treatment prior to difficulties becoming chronic. Besides, general practitioners should be aware of PTSD symptoms, and careful consideration should be given to routine screening for PTSD during the reconstruction process following earthquakes. Above all, post-disaster mental health recovery programs that include early identification, on-going monitoring, prevention and intervention programs, and sustained psychosocial support are needed for the high-risk population of earthquake survivors.

Acknowledgments: Role of funding source: Work on this manuscript was supported by the National Natural Science Foundation of China (Xu Liu, grant number 71774166, Yuan Liu, grant number 71573270, Lulu Zhang, grant number 91224005, Lulu Zhang, grant number 71774167, Lulu Zhang, grant number 71233008) and Chinese Defense Program of Science and Technology (Xu Liu, grant number 3605021, Lulu Zhang, grant number AWS12J002).

Author Contributions: Bihan Tang and Qiangyu Deng discussed and developed the question for this review. Bihan Tang and Qiangyu Deng carried out the searches. Qiangyu Deng and Junqiang Dong assessed the eligibility of the studies for inclusion, extracted data. Bihan Tang carried out all analysis. All authors were involved in interpreted and discussed results. Bihan Tang and Qiangyu Deng wrote the first draft of this paper and it was reviewed by Deborah Glik and Lulu Zhang. All authors agreed on the final draft of this study. Lulu Zhang is the guarantor.

Conflicts of Interest: The authors declare no conflict of interest. 


\section{Appendix A}

Table A1. General characteristic of the included studies with regard to risk factors for PTSD after earthquakes.

\begin{tabular}{|c|c|c|c|c|c|c|c|c|c|c|c|c|c|}
\hline No. & Author & $\begin{array}{c}\text { Publication } \\
\text { Year }\end{array}$ & Country & $\begin{array}{l}\text { Earthquake } \\
\text { Year }\end{array}$ & Magnitude & Population & $\begin{array}{l}\text { Study } \\
\text { Design }\end{array}$ & Identification of PTSD & $\begin{array}{l}\text { Sample } \\
\text { Size }\end{array}$ & $\begin{array}{c}\text { PTSD } \\
\text { Prevalence \% }\end{array}$ & $\begin{array}{l}\text { Time after } \\
\text { Disaster }\end{array}$ & $\underset{\%}{\operatorname{Male}}$ & Quality \\
\hline 1 & Ali & 2012 & Pakistan & 2005 & 7.6 & adults & cross-section & $\begin{array}{c}\text { Davidson Trauma Scale } \\
\text { (DTS) }\end{array}$ & 300 & 41.30 & 30 months & 60.7 & 8 \\
\hline 2 & Altindag & 2005 & Turkey & 1998 & 6.3 & adults & cross-section & $\begin{array}{l}\text { Diagnostic and Statistical } \\
\text { Manual of Mental } \\
\text { Disorders, Fourth Edition }\end{array}$ & 105 & $42.00,23.00$ & $\begin{array}{c}1,13 \\
\text { months }\end{array}$ & 47.6 & 8 \\
\hline 3 & Cairo & 2010 & Peru & 2007 & 8.0 & adults & cross-section & $\begin{array}{l}\text { a Spanish translation of the } \\
\text { civilian version of the PTSD } \\
\text { Checklist (PCL) }\end{array}$ & 298 & 25.20 & 5 months & 31.88 & 7 \\
\hline 5 & Cenat & 2014 & Haiti & 2010 & 7.0 & adults & cross-section & $\begin{array}{c}\text { Impact of event } \\
\text { scale-Revised (IES-R) }\end{array}$ & 1355 & 36.75 & 30 months & 51.29 & 8 \\
\hline 6 & Cenat & 2015 & Haiti & 2010 & 7.0 & children & cross-section & $\begin{array}{l}\text { Impact of event } \\
\text { scale-Revised (IES-R) }\end{array}$ & 872 & 36.93 & 30 months & 43.7 & 8 \\
\hline 7 & Cerda & 2013 & Haiti & 2010 & 7.0 & adults & cross-section & DSM-IV & 1315 & 24.60 & $\begin{array}{c}2-4 \\
\text { months }\end{array}$ & 28.9 & 7 \\
\hline 8 & Chen & 2007 & $\begin{array}{c}\text { China } \\
\text { (Taiwan) }\end{array}$ & 1999 & 7.3 & adults & cross-section & $\begin{array}{l}\text { The Davidson Trauma Scale } \\
\text { (DTS) }\end{array}$ & 6412 & 20.90 & 24 months & 38.8 & 8 \\
\hline 10 & Cheng & 2014 & China & 2008 & 8.0 & adults & case-control & $\begin{array}{l}\text { the civilian version of the } \\
\text { PTSD Checklist (PCL) }\end{array}$ & 565 & 20.00 & 36 months & 41.6 & 8 \\
\hline 11 & Cheng & 2015 & China & 2008 & 8.0 & adults & cross-section & $\begin{array}{c}\text { Structured Clinical } \\
\text { Interview for DSM-IV Axis } \\
\text { I Disorders (SCID-I/NP) }\end{array}$ & 182 & 39.60 & 12 months & 34.8 & 8 \\
\hline 12 & Chou & 2005 & $\begin{array}{c}\text { China } \\
\text { (Taiwan) }\end{array}$ & 1999 & 7.3 & adults & cross-section & DSM-IV & 442 & 7.90 & 6 months & 48.4 & 8 \\
\hline 13 & Chou & 2007 & $\begin{array}{l}\text { China } \\
\text { (Taiwan) }\end{array}$ & 1999 & 7.3 & adults & cross-section & DSM-IV & 216 & 8.30 & $\begin{array}{l}6,24,36 \\
\text { months }\end{array}$ & 45.8 & 8 \\
\hline 14 & Cofini & 2015 & Italy & 2009 & 6.3 & adults & cross-section & $\begin{array}{c}\text { Davidson Trauma Scale } \\
\text { (DTS) }\end{array}$ & 281 & 43.00 & 12 months & 46 & 9 \\
\hline 15 & Eksi & 2007 & Turkey & 1999 & 7.4 & children & cross-section & $\begin{array}{l}\text { The Clinician-Administered } \\
\text { Post-Traumatic Stress } \\
\text { Disorder Scale (CAPS) }\end{array}$ & 160 & 60.00 & 6-20 weeks & 36.25 & 7 \\
\hline
\end{tabular}


Table A1. Cont.

\begin{tabular}{|c|c|c|c|c|c|c|c|c|c|c|c|c|c|}
\hline No. & Author & $\begin{array}{l}\text { Publication } \\
\text { Year }\end{array}$ & Country & $\begin{array}{l}\text { Earthquake } \\
\text { Year }\end{array}$ & Magnitude & Population & $\begin{array}{l}\text { Study } \\
\text { Design }\end{array}$ & Identification of PTSD & $\begin{array}{c}\text { Sample } \\
\text { Size }\end{array}$ & $\begin{array}{c}\text { PTSD } \\
\text { Prevalence \% }\end{array}$ & $\begin{array}{l}\text { Time after } \\
\text { Disaster }\end{array}$ & $\begin{array}{c}\text { Male } \\
\%\end{array}$ & Quality \\
\hline 16 & Fan & 2015 & China & 2008 & 8.0 & children & cross-section & $\begin{array}{c}\text { The Posttraumatic Stress } \\
\text { Disorder Self-Rating Scale } \\
\text { (PTSD-SS) }\end{array}$ & 1573 & $\begin{array}{l}21.00,23.35 \\
13.50,14.70\end{array}$ & $\begin{array}{l}6,12,18,24 \\
\text { months }\end{array}$ & 45.77 & 9 \\
\hline 17 & Fan & 2011 & China & 2008 & 8.0 & children & cross-section & $\begin{array}{l}\text { The Posttraumatic Stress } \\
\text { Disorder Self-Rating Scale } \\
\text { (PTSD-SS) }\end{array}$ & 2081 & 15.80 & 6 months & 45.9 & 9 \\
\hline 18 & Gigantesco & 2013 & Italy & 2009 & 6.3 & adults & cross-section & $\begin{array}{l}\text { Mini-International } \\
\text { Neuropsychiatric Interview } \\
\text { (MINI) }\end{array}$ & 957 & 4.10 & $\begin{array}{l}\text { 14-19 } \\
\text { months }\end{array}$ & 49.2 & 8 \\
\hline 19 & Guo & 2015 & China & 2008 & 8.0 & adults & cross-section & $\begin{array}{c}\text { Impact of Event } \\
\text { Scale-Revised (IES-R) }\end{array}$ & 1362 & 22.10 & 6 months & 36 & 7 \\
\hline 20 & Guo & 2014 & China & 2008 & 8.0 & adults & cross-section & $\begin{array}{c}\text { Impact of Event } \\
\text { Scale-Revised (IES-R) }\end{array}$ & 1066 & $\begin{array}{l}58.20,22.10 \\
19.80,8.00\end{array}$ & $\begin{array}{l}2,8,14,26 \\
44 \text { months }\end{array}$ & 37.3 & 7 \\
\hline 21 & Hashmi & 2011 & Pakistan & 2005 & 7.6 & adults & cross-section & $\begin{array}{l}\text { the civilian version of the } \\
\text { PTSD Checklist (PCL) }\end{array}$ & 361 & 51.50 & 6 months & 43 & 8 \\
\hline 22 & Hikichi & 2016 & Japan & 2011 & 9.0 & adults & cross-section & $\begin{array}{c}\text { the Screening } \\
\text { Questionnaire for } \\
\text { Disaster-Related Mental } \\
\text { Health }\end{array}$ & 3567 & 11.40 & 30 months & 43.5 & 8 \\
\hline 23 & Jia & 2010 & China & 2008 & 8.0 & children & cross-section & $\begin{array}{l}\text { the self-report Child } \\
\text { Posttraumatic Stress } \\
\text { Disorder Reaction Index } \\
\text { (CPTSD-RI) }\end{array}$ & 596 & 12.40 & 15 months & 49.8 & 9 \\
\hline 24 & Jia & 2010 & China & 2008 & 8.0 & adults & cross-section & $\begin{array}{l}\text { the self-report Child } \\
\text { Posttraumatic Stress } \\
\text { Disorder Reaction Index } \\
\text { (CPTSD-RI) }\end{array}$ & 276 & 15.20 & 15 months & 53.6 & 7 \\
\hline 25 & Jin & 2015 & China & 2010 & 7.1 & children & cross-section & $\begin{array}{l}\text { the civilian version of the } \\
\text { PTSD Checklist (PCL) }\end{array}$ & 459 & $10.90,5.80$ & $\begin{array}{l}6,24 \\
\text { months }\end{array}$ & 40.50 & 8 \\
\hline 26 & Jin & 2014 & China & 2010 & 7.1 & children & cross-section & $\begin{array}{l}\text { the civilian version of the } \\
\text { PTSD Checklist (PCL) }\end{array}$ & 850 & 8.94 & 36 months & 44.8 & 7 \\
\hline 27 & Kadak & 2013 & Turkey & 2011 & 7.2 & children & cross-section & $\begin{array}{l}\text { Child Posttraumatic Stress } \\
\text { Disorder-Reaction Index } \\
\text { (CPTSD-R I) }\end{array}$ & 738 & 40.69 & 6 months & 55.01 & 8 \\
\hline 28 & Kun & 2009 & China & 2008 & 8.0 & adults & cross-section & $\begin{array}{l}\text { The Harvard Trauma } \\
\text { Questionnaire (HTQ) }\end{array}$ & 446 & 45.50 & 2.5 months & 49.5 & 10 \\
\hline
\end{tabular}


Table A1. Cont.

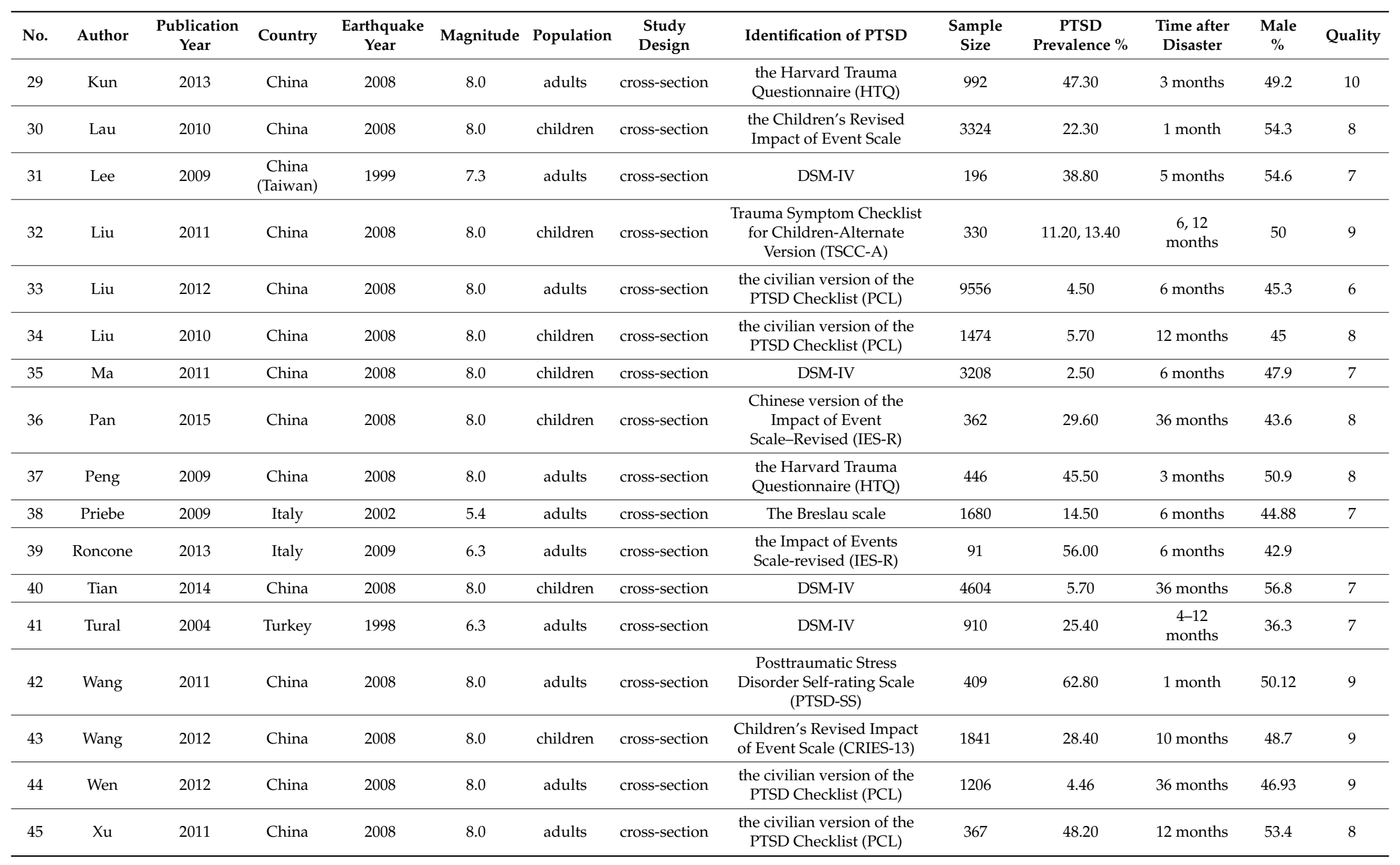


Table A1. Cont.

\begin{tabular}{|c|c|c|c|c|c|c|c|c|c|c|c|c|c|}
\hline No. & Author & $\begin{array}{c}\text { Publication } \\
\text { Year }\end{array}$ & Country & $\begin{array}{l}\text { Earthquake } \\
\text { Year }\end{array}$ & Magnitude & Population & $\begin{array}{l}\text { Study } \\
\text { Design }\end{array}$ & Identification of PTSD & $\begin{array}{c}\text { Sample } \\
\text { Size }\end{array}$ & $\begin{array}{c}\text { PTSD } \\
\text { Prevalence \% }\end{array}$ & $\begin{array}{l}\text { Time after } \\
\text { Disaster }\end{array}$ & $\underset{\%}{\text { Male }}$ & Quality \\
\hline 46 & $\mathrm{Xu}$ & 2011 & China & 2008 & 8.0 & adults & cross-section & $\begin{array}{l}\text { the civilian version of the } \\
\text { PTSD Checklist (PCL) }\end{array}$ & 2080 & 67.07 & $\begin{array}{l}12-16 \\
\text { months }\end{array}$ & 47.26 & 8 \\
\hline 47 & Zhang & 2015 & China & 2008 & 8.0 & adults & cross-section & $\begin{array}{l}\text { the civilian version of the } \\
\text { PTSD Checklist (PCL) }\end{array}$ & 684 & 9.20 & 60 months & 42.1 & 8 \\
\hline 48 & Zhang & 2015 & China & 2008 & 8.0 & adults & cross-section & $\begin{array}{l}\text { the civilian version of the } \\
\text { PTSD Checklist (PCL) }\end{array}$ & 360 & 10.30 & 36 months & 55.6 & 9 \\
\hline 49 & Zhang & 2011 & China & 2008 & 8.0 & adults & cross-section & $\begin{array}{l}\text { the civilian version of the } \\
\text { PTSD Checklist (PCL) }\end{array}$ & 1181 & 26.30 & 12 months & 37.3 & 10 \\
\hline 50 & Zhang & 2012 & China & 2008 & 8.0 & adults & cross-section & $\begin{array}{l}\text { the civilian version of the } \\
\text { PTSD Checklist (PCL) }\end{array}$ & 274 & 26.30 & 14 months & 38 & 8 \\
\hline 51 & Zhang & 2012 & China & 2010 & 7.1 & adults & cross-section & $\begin{array}{l}\text { the civilian version of the } \\
\text { PTSD Checklist (PCL) }\end{array}$ & 505 & 33.70 & $\begin{array}{c}3-4 \\
\text { months }\end{array}$ & 53.5 & 8 \\
\hline 52 & Zhou & 2013 & China & 2008 & 8.0 & adults & cross-section & $\begin{array}{l}\text { a Chinese version of the } \\
\text { Structured Clinical } \\
\text { Interview for Diagnostic } \\
\text { and Statistical Manual } \\
\text { (DSM)-IV axis I disorders } \\
\text { (SCID-I/P) }\end{array}$ & 14,207 & 15.57 & 6 months & 48.42 & 8 \\
\hline
\end{tabular}

${ }^{*}$ No.: Number.

Table A2. Risk Factors for PTSD after earthquakes in adults.

\begin{tabular}{|c|c|c|c|c|c|c|c|c|c|c|c|c|}
\hline \multirow{2}{*}{ Factors } & \multicolumn{4}{|c|}{ All Studies } & \multicolumn{2}{|c|}{ High Quality } & \multicolumn{2}{|c|}{ Adjustment } & \multicolumn{2}{|c|}{ Within 6 Months } & \multicolumn{2}{|c|}{ High Magnitude } \\
\hline & $n$ & OR $(95 \% \mathrm{CI})$ & $I^{2}$ ( $p$ Value) & Egger Test & $n$ & OR $(95 \% \mathrm{CI})$ & $n$ & OR $(95 \% \mathrm{CI})$ & $n$ & OR $(95 \% \mathrm{CI})$ & $n$ & OR $(95 \% \mathrm{CI})$ \\
\hline \multicolumn{13}{|l|}{ Basic characteristics } \\
\hline Age (older) & 32 & $\begin{array}{c}1.17 \\
(1.08-1.27)\end{array}$ & $\begin{array}{c}73.2 \% \\
(p<0.001)\end{array}$ & $p=0.013^{*}$ & 20 & $\begin{array}{c}1.07 \\
(0.98-1.17)\end{array}$ & 25 & $\begin{array}{c}1.12 \\
(1.03-1.22)\end{array}$ & 12 & $\begin{array}{c}1.49 \\
(1.13-1.97)\end{array}$ & 26 & $\begin{array}{c}1.16 \\
(1.07-1.27)\end{array}$ \\
\hline Gender (female) & 42 & $\begin{array}{c}1.85 \\
(1.69-2.02)\end{array}$ & $\begin{array}{c}51.1 \% \\
(p<0.001)\end{array}$ & $p=0.855$ & 28 & $\begin{array}{c}1.94 \\
(1.74-2.15)\end{array}$ & 33 & $\begin{array}{c}1.85 \\
(1.69-2.03)\end{array}$ & 16 & $\begin{array}{c}2.01 \\
(1.67-2.42)\end{array}$ & 34 & $\begin{array}{c}1.82 \\
(1.66-1.99)\end{array}$ \\
\hline Education (higher) & 30 & $\begin{array}{c}0.81 \\
(0.75-0.87) \\
\end{array}$ & $\begin{array}{c}33.3 \% \\
(p=0.041)\end{array}$ & $p=0.550$ & 18 & $\begin{array}{c}0.86 \\
(0.78-0.95) \\
\end{array}$ & 22 & $\begin{array}{c}0.83 \\
(0.76-0.90) \\
\end{array}$ & 12 & $\begin{array}{c}0.78 \\
(0.67-0.89) \\
\end{array}$ & 22 & $\begin{array}{c}0.81 \\
(0.74-0.88) \\
\end{array}$ \\
\hline Marry (not) & 25 & $\begin{array}{c}1.03 \\
(0.82-1.28)\end{array}$ & $\begin{array}{c}79.6 \% \\
(p<0.001)\end{array}$ & $p=0.226$ & 14 & $\begin{array}{c}1.35 \\
(0.93-1.97)\end{array}$ & 19 & $\begin{array}{c}1.04 \\
(0.80-1.35)\end{array}$ & 11 & $\begin{array}{c}0.95 \\
(0.52-1.72)\end{array}$ & 14 & $\begin{array}{c}1.35 \\
(0.93-1.97)\end{array}$ \\
\hline
\end{tabular}


Table A2. Cont.

\begin{tabular}{|c|c|c|c|c|c|c|c|c|c|c|c|c|}
\hline \multirow{2}{*}{ Factors } & \multicolumn{4}{|c|}{ All Studies } & \multicolumn{2}{|c|}{ High Quality } & \multicolumn{2}{|c|}{ Adjustment } & \multicolumn{2}{|c|}{ Within 6 Months } & \multicolumn{2}{|c|}{ High Magnitude } \\
\hline & $n$ & OR $(95 \% \mathrm{CI})$ & $I^{2}$ ( $p$ Value) & Egger Test & $n$ & OR $(95 \% \mathrm{CI})$ & $n$ & OR $(95 \% \mathrm{CI})$ & $n$ & OR $(95 \% \mathrm{CI})$ & $n$ & OR $(95 \% \mathrm{CI})$ \\
\hline Religion (yes) & 5 & $\begin{array}{c}1.12 \\
(0.54-2.34) \\
\end{array}$ & $\begin{array}{c}72.0 \% \\
(p=0.006) \\
\end{array}$ & $p=0.661$ & 5 & $\begin{array}{c}1.12 \\
(0.54-2.34) \\
\end{array}$ & 3 & $\begin{array}{c}0.97 \\
(0.27-3.52) \\
\end{array}$ & 1 & $\begin{array}{c}2.54 \\
(0.86-7.52) \\
\end{array}$ & 4 & $\begin{array}{c}1.07 \\
(0.42-2.76) \\
\end{array}$ \\
\hline Ethnicity (minority) & 12 & $\begin{array}{c}1.17 \\
(0.83-1.66) \\
\end{array}$ & $\begin{array}{c}82.9 \% \\
(p<0.001) \\
\end{array}$ & $p=0.490$ & 11 & $\begin{array}{c}1.19 \\
(0.83-1.73) \\
\end{array}$ & 8 & $\begin{array}{c}1.30 \\
(0.83-2.05) \\
\end{array}$ & 3 & $\begin{array}{c}1.77 \\
(1.12-2.79) \\
\end{array}$ & 12 & $\begin{array}{c}1.17 \\
(0.83-1.66) \\
\end{array}$ \\
\hline Prior trauma (yes) & 2 & $\begin{array}{c}1.63 \\
(1.10-2.41) \\
\end{array}$ & $\begin{array}{c}55.3 \% \\
(p=0.135)\end{array}$ & - & 1 & $\begin{array}{c}2.07 \\
(1.33-3.23) \\
\end{array}$ & 1 & $\begin{array}{c}1.38 \\
(1.03-1.85) \\
\end{array}$ & 1 & $\begin{array}{c}2.07 \\
(1.33-3.23) \\
\end{array}$ & 1 & $\begin{array}{c}2.07 \\
(1.33-3.23) \\
\end{array}$ \\
\hline Socio-economic status (low) & 16 & $\begin{array}{c}1.74 \\
(1.24-2.45)\end{array}$ & $\begin{array}{c}89.0 \% \\
(p<0.001)\end{array}$ & $p=0.532$ & 9 & $\begin{array}{c}2.91 \\
(1.56-5.41)\end{array}$ & 15 & $\begin{array}{c}1.68 \\
(1.18-2.40)\end{array}$ & 3 & $\begin{array}{c}1.73 \\
(0.71-4.17)\end{array}$ & 16 & $\begin{array}{c}1.74 \\
(1.24-2.45)\end{array}$ \\
\hline Disease history (yes) & 6 & $\begin{array}{c}1.19 \\
(0.93-1.54)\end{array}$ & $\begin{array}{c}0.0 \% \\
(p=0.972)\end{array}$ & $p=0.381$ & 6 & $\begin{array}{c}1.19 \\
(0.93-1.54)\end{array}$ & 2 & $\begin{array}{c}1.21 \\
(0.89-1.65)\end{array}$ & 1 & $\begin{array}{c}1.27 \\
(0.49-3.33)\end{array}$ & 4 & $\begin{array}{c}1.20 \\
(0.92-1.56)\end{array}$ \\
\hline \multicolumn{13}{|l|}{ Trauma characteristics } \\
\hline Being trapped (yes) & 6 & $\begin{array}{c}1.81 \\
(1.47-2.24) \\
\end{array}$ & $\begin{array}{c}0.0 \% \\
(p=0.664) \\
\end{array}$ & $p=0.784$ & 3 & $\begin{array}{c}1.68 \\
(1.21-2.34) \\
\end{array}$ & 5 & $\begin{array}{c}1.75 \\
(1.41-2.18) \\
\end{array}$ & 2 & $\begin{array}{c}1.85 \\
(1.41-2.44) \\
\end{array}$ & 5 & $\begin{array}{c}1.89 \\
(1.50-2.37) \\
\end{array}$ \\
\hline fear (yes) & 4 & $\begin{array}{c}2.97 \\
(1.78-4.95) \\
\end{array}$ & $\begin{array}{c}92.9 \% \\
(p<0.001) \\
\end{array}$ & $p=0.659$ & 4 & $\begin{array}{c}2.97 \\
(1.78-4.95) \\
\end{array}$ & 3 & $\begin{array}{c}3.55 \\
(1.90-6.63) \\
\end{array}$ & - & - & 4 & $\begin{array}{c}2.97 \\
(1.78-4.95) \\
\end{array}$ \\
\hline Injure (yes) & 14 & $\begin{array}{c}2.06 \\
(1.33-3.19) \\
\end{array}$ & $\begin{array}{c}90.0 \% \\
(p<0.001)\end{array}$ & $p=0.185$ & 9 & $\begin{array}{c}1.79 \\
(0.92-3.50) \\
\end{array}$ & 6 & $\begin{array}{c}1.45 \\
(0.80-2.62) \\
\end{array}$ & 5 & $\begin{array}{c}1.89 \\
(0.79-4.54) \\
\end{array}$ & 10 & $\begin{array}{c}2.08 \\
(1.22-3.56) \\
\end{array}$ \\
\hline Witness injury/death (yes) & 7 & $\begin{array}{c}1.62 \\
(0.92-2.85) \\
\end{array}$ & $\begin{array}{c}90.5 \% \\
(p<0.001) \\
\end{array}$ & $p=0.383$ & 4 & $\begin{array}{c}1.64 \\
(0.59-4.54) \\
\end{array}$ & 4 & $\begin{array}{c}1.19 \\
(0.70-2.03) \\
\end{array}$ & 2 & $\begin{array}{c}0.98 \\
(0.45-2.11) \\
\end{array}$ & 7 & $\begin{array}{c}1.62 \\
(0.92-2.85) \\
\end{array}$ \\
\hline Bereavement (yes) & 23 & $\begin{array}{c}2.49 \\
(2.04-3.04) \\
\end{array}$ & $\begin{array}{c}70.8 \% \\
(p<0.001) \\
\end{array}$ & $p=0.465$ & 17 & $\begin{array}{c}2.56 \\
(1.97-3.32) \\
\end{array}$ & 15 & $\begin{array}{c}2.36 \\
(1.89-2.93) \\
\end{array}$ & 8 & $\begin{array}{c}2.65 \\
(1.78-3.93) \\
\end{array}$ & 17 & $\begin{array}{c}2.61 \\
(2.07-3.29) \\
\end{array}$ \\
\hline \multicolumn{13}{|l|}{ Post-trauma characteristics } \\
\hline Social support (yes) & 14 & $\begin{array}{c}0.81 \\
(0.74-0.89) \\
\end{array}$ & $\begin{array}{c}94.7 \% \\
(p<0.001) \\
\end{array}$ & $p=0.103$ & 8 & $\begin{array}{c}0.82 \\
(0.74-0.91) \\
\end{array}$ & 8 & $\begin{array}{c}0.72 \\
(0.65-0.80) \\
\end{array}$ & 4 & $\begin{array}{c}1.11 \\
(0.83-1.48) \\
\end{array}$ & 8 & $\begin{array}{c}0.83 \\
(0.76-0.92) \\
\end{array}$ \\
\hline Employment (no) & 14 & $\begin{array}{c}2.07 \\
(1.49-2.88) \\
\end{array}$ & $\begin{array}{c}85.5 \% \\
(p<0.001)\end{array}$ & $p=0.996$ & 12 & $\begin{array}{c}2.19 \\
(1.50-3.20)\end{array}$ & 10 & $\begin{array}{c}2.34 \\
(1.59-3.43)\end{array}$ & 6 & $\begin{array}{c}2.61 \\
(1.55-4.39)\end{array}$ & 12 & $\begin{array}{c}2.31 \\
(1.63-3.29)\end{array}$ \\
\hline Loss of property (yes) & 11 & $\begin{array}{c}1.67 \\
(1.31-2.15)\end{array}$ & $\begin{array}{c}60.2 \% \\
(p=0.005)\end{array}$ & $p=0.005^{*}$ & 9 & $\begin{array}{c}1.68 \\
(1.25-2.25)\end{array}$ & 7 & $\begin{array}{c}1.40 \\
(1.15-1.71)\end{array}$ & 4 & $\begin{array}{c}1.47 \\
(1.07-2.02)\end{array}$ & 10 & $\begin{array}{c}1.58 \\
(1.24-2.03)\end{array}$ \\
\hline House damage (yes) & 21 & $\begin{array}{c}1.87 \\
(1.52-2.30) \\
\end{array}$ & $\begin{array}{c}60.6 \% \\
(p<0.001)\end{array}$ & $p=0.475$ & 17 & $\begin{array}{c}2.12 \\
(1.71-2.63) \\
\end{array}$ & 13 & $\begin{array}{c}1.92 \\
(1.49-2.49) \\
\end{array}$ & 8 & $\begin{array}{c}2.06 \\
(1.45-2.94) \\
\end{array}$ & 16 & $\begin{array}{c}1.98 \\
(1.58-2.48) \\
\end{array}$ \\
\hline Involved in rescue (yes) & 2 & $\begin{array}{c}2.30 \\
(0.39-13.57)\end{array}$ & $\begin{array}{c}98.1 \% \\
(p<0.001)\end{array}$ & - & 2 & $\begin{array}{c}2.30 \\
(0.39-13.57)\end{array}$ & 2 & $\begin{array}{c}2.30 \\
(0.39-13.57)\end{array}$ & 1 & $\begin{array}{c}5.69 \\
(4.04-8.00)\end{array}$ & 1 & $\begin{array}{c}5.69 \\
(4.04-8.00)\end{array}$ \\
\hline
\end{tabular}

* trim and fill: Age (older) 1.05 (0.96-1.15); Loss of property (yes) 1.30 (1.01-1.68). 
Table A3. Risk Factors for PTSD after earthquakes in children.

\begin{tabular}{|c|c|c|c|c|c|c|c|c|c|c|c|c|}
\hline \multirow{2}{*}{ Factors } & \multicolumn{4}{|c|}{ All Studies } & \multicolumn{2}{|c|}{ High Quality } & \multicolumn{2}{|c|}{ Adjustment } & \multicolumn{2}{|c|}{ Within 6 Months } & \multicolumn{2}{|c|}{ High Magnitude } \\
\hline & $n$ & OR $(95 \% \mathrm{CI})$ & $I^{2}(p$ Value $)$ & Egger Test & $n$ & OR $(95 \% \mathrm{CI})$ & $n$ & OR $(95 \% \mathrm{CI})$ & $n$ & OR $(95 \% \mathrm{CI})$ & $n$ & OR $(95 \% \mathrm{CI})$ \\
\hline \multicolumn{13}{|l|}{ Basic characteristics } \\
\hline Age (older) & 7 & $\begin{array}{c}1.34 \\
(1.12-1.61)\end{array}$ & $\begin{array}{c}42.2 \% \\
(p=0.109)\end{array}$ & $p=0.402$ & 6 & $\begin{array}{c}1.40 \\
(1.15-1.71)\end{array}$ & 5 & $\begin{array}{c}1.43 \\
(1.16-1.76)\end{array}$ & 4 & $\begin{array}{c}1.38 \\
(1.06-1.78)\end{array}$ & 6 & $\begin{array}{c}1.40 \\
(1.15-1.70)\end{array}$ \\
\hline Gender (female) & 20 & $\begin{array}{c}1.45 \\
(1.31-1.60)\end{array}$ & $\begin{array}{c}26.5 \% \\
(p=0.135)\end{array}$ & $p=0.138$ & 16 & $\begin{array}{c}1.47 \\
(1.33-1.62)\end{array}$ & 12 & $\begin{array}{c}1.43 \\
(1.20-1.70)\end{array}$ & 8 & $\begin{array}{c}1.48 \\
(1.21-1.81)\end{array}$ & 19 & $\begin{array}{c}1.43 \\
(1.29-1.60)\end{array}$ \\
\hline Education (higher) & 13 & $\begin{array}{c}1.57 \\
(1.11-2.21)\end{array}$ & $\begin{array}{c}77.7 \% \\
(p<0.001)\end{array}$ & $p=0.115$ & 12 & $\begin{array}{c}1.55 \\
(1.08-2.23)\end{array}$ & 7 & $\begin{array}{c}1.36 \\
(0.78-2.37)\end{array}$ & 5 & $\begin{array}{c}1.38 \\
(0.70-2.74)\end{array}$ & 13 & $\begin{array}{c}1.57 \\
(1.11-2.21)\end{array}$ \\
\hline Religion (yes) & 1 & $\begin{array}{c}0.98 \\
(0.44-2.17)\end{array}$ & - & - & 1 & $\begin{array}{c}0.98 \\
(0.44-2.17)\end{array}$ & 1 & $\begin{array}{c}0.98 \\
(0.44-2.17)\end{array}$ & 1 & $\begin{array}{c}0.98 \\
(0.44-2.17)\end{array}$ & 1 & $\begin{array}{c}0.98 \\
(0.44-2.17)\end{array}$ \\
\hline Ethnicity (minority) & 8 & $\begin{array}{c}1.39 \\
(0.97-1.98) \\
\end{array}$ & $\begin{array}{c}0.0 \% \\
(p=0.900)\end{array}$ & $p=0.645$ & 6 & $\begin{array}{c}1.35 \\
(0.94-1.94)\end{array}$ & 8 & $\begin{array}{c}1.39 \\
(0.97-1.98) \\
\end{array}$ & 2 & $\begin{array}{c}1.04 \\
(0.36-2.99)\end{array}$ & 8 & $\begin{array}{c}1.39 \\
(0.97-1.98)\end{array}$ \\
\hline Prior trauma (yes) & 1 & $\begin{array}{c}0.94 \\
(0.62-1.42)\end{array}$ & - & - & 1 & $\begin{array}{c}0.94 \\
(0.62-1.42)\end{array}$ & 1 & $\begin{array}{c}0.94 \\
(0.62-1.42)\end{array}$ & 1 & $\begin{array}{c}0.94 \\
(0.62-1.42)\end{array}$ & 1 & $\begin{array}{c}0.94 \\
(0.62-1.42)\end{array}$ \\
\hline \multicolumn{13}{|l|}{ Trauma characteristics } \\
\hline Being trapped (yes) & 9 & $\begin{array}{c}1.94 \\
(1.52-2.47)\end{array}$ & $\begin{array}{c}0 \% \\
(p=0.812)\end{array}$ & $p=0.463$ & 8 & $\begin{array}{c}1.97 \\
(1.52-2.56)\end{array}$ & 7 & $\begin{array}{c}2.21 \\
(1.67-2.92)\end{array}$ & 4 & $\begin{array}{c}1.90 \\
(1.33-2.72)\end{array}$ & 9 & $\begin{array}{c}1.94 \\
(1.52-2.47)\end{array}$ \\
\hline fear (yes) & 2 & $\begin{array}{c}2.24 \\
(1.52-3.32)\end{array}$ & $\begin{array}{c}0.0 \% \\
(p=0.777)\end{array}$ & - & 2 & $\begin{array}{c}2.24 \\
(1.52-3.32)\end{array}$ & 1 & $\begin{array}{c}2.32 \\
(1.47-3.67)\end{array}$ & 1 & $\begin{array}{c}2.04 \\
(0.95-4.36)\end{array}$ & 2 & $\begin{array}{c}2.24 \\
(1.52-3.32)\end{array}$ \\
\hline injury (yes) & 11 & $\begin{array}{c}2.05 \\
(1.67-2.52)\end{array}$ & $\begin{array}{c}4.9 \% \\
(p=0.397)\end{array}$ & $p=0.379$ & 8 & $\begin{array}{c}2.04 \\
(1.59-2.62)\end{array}$ & 9 & $\begin{array}{c}2.17 \\
(1.69-2.80)\end{array}$ & 5 & $\begin{array}{c}2.43 \\
(1.77-3.35)\end{array}$ & 11 & $\begin{array}{c}2.05 \\
(1.67-2.52)\end{array}$ \\
\hline Witness injury/death (yes) & 6 & $\begin{array}{c}2.01 \\
(1.44-2.80)\end{array}$ & $\begin{array}{c}64.9 \% \\
(p=0.014)\end{array}$ & $p=0.027^{*}$ & 4 & $\begin{array}{c}2.26 \\
(1.59-3.22)\end{array}$ & 4 & $\begin{array}{c}2.00 \\
(1.32-3.04)\end{array}$ & 2 & $\begin{array}{c}2.68 \\
(1.59-4.54)\end{array}$ & 6 & $\begin{array}{c}2.01 \\
(1.44-2.80)\end{array}$ \\
\hline Bereavement (yes) & 18 & $\begin{array}{c}2.24 \\
(1.95-2.56)\end{array}$ & $\begin{array}{c}19.7 \% \\
(p=0.219)\end{array}$ & $p=0.217$ & 15 & $\begin{array}{c}2.33 \\
(2.02-2.69)\end{array}$ & 11 & $\begin{array}{c}2.33 \\
(1.82-2.99)\end{array}$ & 8 & $\begin{array}{c}2.30 \\
(1.72-3.07)\end{array}$ & 17 & $\begin{array}{c}2.28 \\
(1.97-2.65)\end{array}$ \\
\hline \multicolumn{13}{|l|}{ Post-trauma characteristics } \\
\hline Social support (yes) & 2 & $\begin{array}{c}0.94 \\
(0.85-1.03) \\
\end{array}$ & $\begin{array}{c}95.4 \% \\
(p<0.001) \\
\end{array}$ & - & - & - & 2 & $\begin{array}{c}0.94 \\
(0.85-1.03) \\
\end{array}$ & 1 & $\begin{array}{c}0.89 \\
(0.86-0.93) \\
\end{array}$ & 2 & $\begin{array}{c}0.94 \\
(0.85-1.03) \\
\end{array}$ \\
\hline Loss of property (yes) & 11 & $\begin{array}{c}1.76 \\
(1.53-2.02)\end{array}$ & $\begin{array}{c}0.0 \% \\
(p=0.696)\end{array}$ & $p=0.276$ & 10 & $\begin{array}{c}1.93 \\
(1.60-2.33)\end{array}$ & 7 & $\begin{array}{c}1.63 \\
(1.39-1.92)\end{array}$ & 4 & $\begin{array}{c}1.80 \\
(1.35-2.39)\end{array}$ & 11 & $\begin{array}{c}1.76 \\
(1.53-2.02)\end{array}$ \\
\hline House damage (yes) & 9 & $\begin{array}{c}1.38 \\
(0.98-1.94)\end{array}$ & $\begin{array}{c}55.1 \% \\
(p=0.023)\end{array}$ & $p=0.308$ & 7 & $\begin{array}{c}1.32 \\
(0.87-1.98)\end{array}$ & 8 & $\begin{array}{c}1.22 \\
(0.94-1.59)\end{array}$ & 6 & $\begin{array}{c}1.17 \\
(0.85-1.62)\end{array}$ & 9 & $\begin{array}{c}1.38 \\
(0.98-1.94)\end{array}$ \\
\hline
\end{tabular}




\section{References}

1. Aker, A.T. 1999 Marmara earthquakes: A review of epidemiologic findings and community mental health policies. Turk Psikiyatr. Derg. 2006, 17, 204-212.

2. Ali, M.; Farooq, N.; Bhatti, M.A.; Kuroiwa, C. Assessment of prevalence and determinants of posttraumatic stress disorder in survivors of earthquake in Pakistan using Davidson Trauma Scale. J. Affect. Disord. 2012, 136, 238-243. [CrossRef] [PubMed]

3. Zhang, W.; Duan, G.; Xu, Q.; Jia, Z.; Bai, Z.; Liu, W. A Cross-sectional study on posttraumatic stress disorder and general psychiatric morbidity among adult survivors 3 years after the Wenchuan earthquake, China. Asia Pac. J. Public Health 2015, 27, 860-870. [CrossRef] [PubMed]

4. American Psychiatric Association. Diagnostic and Statistical Manual of Mental Disorders, 5th ed.; American Psychiatric Association: Arlington, VA, USA, 2013.

5. Hong, C.; Efferth, T. Systematic review on post-traumatic stress disorder among survivors of the Wenchuan earthquake. Trauma Violence Abuse 2016, 17, 542-561. [CrossRef] [PubMed]

6. Jin, Y.; Li, J. Prospective study of posttraumatic stress in adolescents 6 and 24 months after the 2010 Yushu earthquake in China. J. Nerv. Ment. Dis. 2015, 203, 679-683. [CrossRef] [PubMed]

7. McFarlane, A.C. Posttraumatic stress disorder: A model of the longitudinal course and the role of risk factors. J. Clin. Psychiatry 2000, 61, 15-20. [PubMed]

8. Harvey, A.G.; Bryant, R.A. The relationship between acute stress disorder and posttraumatic stress disorder: A prospective evaluation of motor vehicle accident survivors. J. Consult. Clin. Psychol. 1998, 66, 507-512. [CrossRef] [PubMed]

9. Liu, M.; Wang, L.; Shi, Z.; Zhang, Z.; Zhang, K.; Shen, J. Mental health problems among children one-year after Sichuan earthquake in China: A follow-up study. PLoS ONE 2011, 6, e14706. [CrossRef] [PubMed]

10. Cerdá, M.; Paczkowski, M.; Galea, S.; Nemethy, K.; Péan, C.; Desvarieux, M. Psychopathology in the aftermath of the Haiti earthquake: A population-based study of posttraumatic stress disorder and major depression. Depression Anxiety 2013, 30, 413-424. [CrossRef] [PubMed]

11. Chen, G.; Shen, H. A cross-sectional study on posttraumatic stress disorder among elderly Qiang citizens 3 years after the Wenchuan earthquake in China. Can. J. Psychiatry 2012, 57, 547-553. [CrossRef] [PubMed]

12. Guo, J.; Wang, X.; Yuan, J.; Zhang, W.; Tian, D.; Qu, Z. The symptoms of posttraumatic stress disorder and depression among adult earthquake survivors in China. J. Nerv. Ment. Dis. 2015, 203, 469-472. [CrossRef] [PubMed]

13. Jia, Z.; Tian, W.; He, X.; Liu, W.; Jin, C.; Ding, H. Mental health and quality of life survey among child survivors of the 2008 Sichuan earthquake. Qual. Life Res. 2010, 19, 1381-1391. [CrossRef] [PubMed]

14. Xu, J.; Song, X. Posttraumatic stress disorder among survivors of the Wenchuan earthquake 1 year after: Prevalence and risk factors. Compr. Psychiatry 2011, 52, 431-437. [CrossRef] [PubMed]

15. Altindag, A.; Ozen, S.; Sir, A. One-year follow-up study of posttraumatic stress disorder among earthquake survivors in Turkey. Compr. Psychiatry 2005, 46, 328-333. [CrossRef] [PubMed]

16. Guo, J.; Wu, P.; Tian, D.; Wang, X.; Zhang, W.; Zhang, X. Post-traumatic stress disorder among adult survivors of the Wenchuan earthquake in China: A repeated cross-sectional study. J. Anxiety Disord. 2014, $28,75-82$. [CrossRef] [PubMed]

17. Zhou, X.; Kang, L.; Sun, X.; Song, H.; Mao, W.; Huang, X. Risk factors of mental illness among adult survivors after the Wenchuan earthquake. Soc. Psychiatry Psychiatr. Epidemiol. 2013, 48, 907-915. [CrossRef] [PubMed]

18. Teramoto, C.; Matsunaga, A.; Nagata, S. Cross-sectional study of social support and psychological distress among displaced earthquake survivors in Japan. Jpn. J. Nurs. Sci. 2015, 12, 320-329. [CrossRef] [PubMed]

19. Ozer, E.J.; Best, S.R.; Lipsey, T.L.; Weiss, D.S. Predictors of posttraumatic stress disorder and symptoms in adults: A meta-analysis. Psychol. Bull. 2003, 129, 52-73. [CrossRef] [PubMed]

20. Trickey, D.; Siddaway, A.P.; Meiser-Stedman, R.; Serpell, L.; Field, A.P. A meta-analysis of risk factors for post-traumatic stress disorder in children and adolescents. Clin. Psychol. Rev. 2012, 32, 122-138. [CrossRef] [PubMed]

21. Brewin, C.R.; Andrews, B.; Valentine, J.D. Meta-analysis of risk factors for posttraumatic stress disorder in trauma-exposed adults. J. Consult. Clin. Psychol. 2000, 68, 748-766. [CrossRef] [PubMed] 
22. Berger, W.; Coutinho, E.S.; Figueira, I.; Marques-Portella, C.; Luz, M.P.; Neylan, T.C. Rescuers at risk: A systematic review and meta-regression analysis of the worldwide current prevalence and correlates of PTSD in rescue workers. Soc. Psychiatry Psychiatr. Epidemiol. 2012, 47, 1001-1011. [CrossRef] [PubMed]

23. Machtinger, E.L.; Wilson, T.C.; Haberer, J.E.; Weiss, D.S. Psychological trauma and PTSD in HIV-positive women: A meta-analysis. AIDS Behav. 2012, 16, 2091-2100. [CrossRef] [PubMed]

24. Porter, M.; Haslam, N. Predisplacement and postdisplacement factors associated with mental health of refugees and internally displaced persons: A meta-analysis. JAMA 2005, 294, 602-612. [CrossRef] [PubMed]

25. Zhang, J.; Zhu, S.; Du, C.; Zhang, Y. Posttraumatic stress disorder and somatic symptoms among child and adolescent survivors following the Lushan earthquake in China: A six-month longitudinal study. J. Psychosom. Res. 2015, 79, 100-106. [CrossRef] [PubMed]

26. Eksi, A.; Braun, K.L.; Ertem-Vehid, H.; Peykerli, G.; Saydam, R.; Toparlak, D. Risk factors for the development of PTSD and depression among child and adolescent victims following a 7.4 magnitude earthquake. Int. J. Psychiatry Clin. Pract. 2007, 11, 190-199. [CrossRef] [PubMed]

27. Celiac Disease. Evidence Reports/Technology Assessments NAD. Available online: http://www.ncbi.nlm. nih.gov/books/NBK35156 (accessed on 18 July 2016).

28. Wells, G.A.; Shea, B.J.; O'Connell, D.; Peterson, J.E.; Welch, V.; Losos, M.; Tugwell, P. The Newcastle-Ottawa Scale (NOS) for Assessing the Quality of Non-Randomized Studies in Meta-Analysis. Appl. Eng. Agric. 2014, 18, 727-734.

29. Tang, B.; Liu, X.; Liu, Y.; Xue, C.; Zhang, L. A meta-analysis of risk factors for depression in adults and children after natural disasters. BMC Public Health 2014, 14, 623. [CrossRef] [PubMed]

30. DerSimonian, R.; Laird, N. Meta-analysis in clinical trials. Control Clin. Trials 1986, 7, 177-188. [CrossRef]

31. Higgins, J.P.; Thompson, S.G.; Deeks, J.J.; Altman, D.G. Measuring inconsistency in meta-analyses. BMJ 2003, 327, 557-560. [CrossRef] [PubMed]

32. Egger, M.; Davey Smith, G.; Schneider, M.; Minder, C. Bias in meta-analysis detected by a simple, graphical test. BMJ 1997, 315, 629-634. [CrossRef] [PubMed]

33. Armenian, H.K.; Morikawa, M.; Melkonian, A.K.; Hovanesian, A.P.; Haroutunian, N.; Saigh, P.A. Loss as a determinant of PTSD in a cohort of adult survivors of the 1988 earthquake in Armenia: Implications for policy. Acta Psychiatr. Scand. 2000, 102, 58-64. [CrossRef] [PubMed]

34. Cénat, J.M.; Derivois, D. Long-term outcomes among child and adolescent survivors of the 2010 Haitian earthquake. Depression Anxiety 2015, 32, 57-63. [CrossRef] [PubMed]

35. Cairo, J.B.; Dutta, S.; Nawaz, H.; Hashmi, S.; Kasl, S.; Bellido, E. The prevalence of posttraumatic stress disorder among adult earthquake survivors in Peru. Disaster Med. Public Health Prep. 2010, 4, $39-46$. [CrossRef]

36. Cenat, J.M.; Derivois, D. Assessment of prevalence and determinants of posttraumatic stress disorder and depression symptoms in adults survivors of earthquake in Haiti after 30 months. J. Affect. Disord. 2014, 159, 111-117. [CrossRef] [PubMed]

37. Chen, C.H.; Tan, H.K.; Liao, L.R.; Chen, H.H.; Chan, C.C.; Cheng, J.J. Long-term psychological outcome of 1999 Taiwan earthquake survivors: A survey of a high-risk sample with property damage. Compr. Psychiatry 2007, 48, 269-275. [CrossRef] [PubMed]

38. Cheng, Y.; Wang, F.; Wen, J.; Shi, Y. Risk Factors of Post-Traumatic Stress Disorder (PTSD) after Wenchuan Earthquake: A Case Control Study. PLoS ONE 2014, 9, e96644. [CrossRef] [PubMed]

39. Cheng, Z.; Ma, N.; Yang, L.; Agho, K.; Stevens, G.; Raphael, B. Depression and Posttraumatic Stress Disorder in Temporary Settlement Residents 1 Year after the Sichuan Earthquake. Asia Pac. J. Public Health 2015, 27, NP1962-NP1972. [CrossRef] [PubMed]

40. Chou, F.H.C.; Su, T.T.P.; Chou, P.; Ou-Yang, W.C.; Lu, M.K.; Chien, I.C. Survey of psychiatric disorders in a Taiwanese village population six months after a major earthquake. J. Formos. Med. Assoc. 2005, 104, 308-317. [PubMed]

41. Chou, F.H.C.; Wu, H.C.; Chou, P.; Su, C.Y.; Tsai, K.Y.; Chao, S.S. Epidemiologic psychiatric studies on post-disaster impact among Chi-Chi earthquake survivors in Yu-Chi, Taiwan. Psychiatry Clin. Neurosci. 2007, 61, 370-378. [CrossRef] [PubMed] 
42. Cofini, V.; Carbonelli, A.; Cecilia, M.R.; Binkin, N.; di Orio, F. Post traumatic stress disorder and coping in a sample of adult survivors of the Italian earthquake. Psychiatry Res. 2015, 229, 353-358. [CrossRef] [PubMed]

43. Fan, F.; Long, K.; Zhou, Y.; Zheng, Y.; Liu, X. Longitudinal trajectories of post-traumatic stress disorder symptoms among adolescents after the Wenchuan earthquake in China. Psychol. Med. 2015, 45, 2885-2896. [CrossRef] [PubMed]

44. Fan, F.; Zhang, Y.; Yang, Y.; Mo, L.; Liu, X. Symptoms of posttraumatic stress disorder, depression, and anxiety among adolescents following the 2008 Wenchuan earthquake in China. J. Trauma. Stress 2011, 24, 44-53. [CrossRef] [PubMed]

45. Gigantesco, A.; Mirante, N.; Granchelli, C.; Diodati, G.; Cofini, V.; Mancini, C. Psychopathological chronic sequelae of the 2009 earthquake in L'Aquila, Italy. J. Affect. Disord. 2013, 148, 265-271. [CrossRef] [PubMed]

46. Hashmi, S.; Petraro, P.; Rizzo, T.; Nawaz, H.; Choudhary, R.; Tessier-Sherman, B. Symptoms of anxiety, depression, and posttraumatic stress among survivors of the 2005 Pakistani earthquake. Disaster Med. Public Health Prep. 2011, 5, 293-299. [CrossRef] [PubMed]

47. Hikichi, H.; Aida, J.; Tsuboya, T.; Kondo, K.; Kawachi, I. Can community social cohesion prevent posttraumatic stress disorder in the aftermath of a disaster? A natural experiment from the 2011 Tohoku earthquake and tsunami. Am. J. Epidemiol. 2016, 183, 902-910. [CrossRef] [PubMed]

48. Jia, Z.; Tian, W.; Liu, W.; Cao, Y.; Yan, J.; Shun, Z. Are the elderly more vulnerable to psychological impact of natural disaster? A population-based survey of adult survivors of the 2008 Sichuan earthquake. BMC Public Health 2010, 10, 1-11. [CrossRef] [PubMed]

49. Jin, Y.; Wang, G. Individual risk factors for PTSD in adolescents from the 2010 earthquake in Yushu: The predictor effect of rumination. Afr. J. Psychiatry 2014, 17. [CrossRef]

50. Kadak, M.T.; Nasiroglu, S.; Boysan, M.; Aydin, A. Risk factors predicting posttraumatic stress reactions in adolescents after 2011 Van earthquake. Compr. Psychiatry 2013, 54, 982-990. [CrossRef] [PubMed]

51. Kun, P.; Chen, X.; Han, S.; Gong, X.; Chen, M.; Zhang, W.; Yao, L. Prevalence of post-traumatic stress disorder in Sichuan Province, China after the 2008 Wenchuan earthquake. Public Health 2009, 123, 703-707. [CrossRef] [PubMed]

52. Kun, P.; Tong, X.; Liu, Y.; Pei, X.; Luo, H. What are the determinants of post-traumatic stress disorder: Age, gender, ethnicity or other? Evidence from 2008 Wenchuan earthquake. Public Health 2013, 127, 644-652. [CrossRef]

53. Lau, J.T.F.; Yu, X.; Zhang, J.; Mak, W.W.S.; Choi, K.C.; Lui, W.W.S. Psychological distress among adolescents in Chengdu, Sichuan at 1 month after the 2008 Sichuan earthquake. J. Urban Health 2010, 87, 504-523. [CrossRef] [PubMed]

54. Lee, C.S.; Chang, J.C.; Liu, C.Y.; Chang, C.J.; Chen, T.H.H.; Chen, C.H. Acculturation, psychiatric comorbidity and posttraumatic stress disorder in a Taiwanese aboriginal population. Soc. Psychiatry Psychiatr. Epidemiol. 2009, 44, 55-62. [CrossRef] [PubMed]

55. Liu, X.; Ma, X.; Hu, X.; Qiu, C.; Wang, Y.; Wang, Q. A risk score for predicting post-traumatic stress disorder in adults in a Chinese earthquake area. J. Int. Med. Res. 2012, 40, 2191-2198. [CrossRef] [PubMed]

56. Liu, Z.; Yang, Y.; Ye, Y.; Zeng, Z.; Xiang, Y.; Yuan, P. One-year follow-up study of post-traumatic stress disorder among adolescents following the Wenchuan earthquake in China. Biosci. Trends 2010, 4, 96-102. [PubMed]

57. Ma, X.; Liu, X.; Hu, X.; Qiu, C.; Wang, Y.; Huang, Y. Risk indicators for post-traumatic stress disorder in adolescents exposed to the 5.12 Wenchuan earthquake in China. Psychiatry Res. 2011, 189, 385-391. [CrossRef] [PubMed]

58. Pan, X.; Liu, W.; Deng, G.; Liu, T.; Yan, J.; Tang, Y. Symptoms of posttraumatic stress disorder, depression, and anxiety among junior high school students in worst-hit areas 3 years after the Wenchuan earthquake in China. Asia Pac. J. Public Health 2015, 27, NP1985-NP1994. [CrossRef] [PubMed]

59. Peng, K.; Shucheng, H.; Xunchui, C.; Lan, Y. Prevalence and risk factors for posttraumatic stress disorder: A cross-sectional study among survivors of the Wenchuan 2008 earthquake in China. Depression Anxiety 2009, 26, 1134-1140.

60. Priebe, S.; Grappasonni, I.; Mari, M.; Dewey, M.; Petrelli, F.; Costa, A. Posttraumatic stress disorder six months after an earthquake: Findings from a community sample in a rural region in Italy. Soc. Psychiatry Psychiatr. Epidemiol. 2009, 44, 393-397. [CrossRef] [PubMed] 
61. Roncone, R.; Giusti, L.; Mazza, M.; Bianchini, V.; Ussorio, D.; Pollice, R. Persistent fear of aftershocks, impairment of working memory, and acute stress disorder predict post-traumatic stress disorder: 6-month follow-up of help seekers following the L'Aquila earthquake. Springerplus 2013, 2, 636. [CrossRef] [PubMed]

62. Tian, Y.; Wong, T.K.S.; Li, J.; Jiang, X. Posttraumatic stress disorder and its risk factors among adolescent survivors three years after an 8.0 magnitude earthquake in China. BMC Public Health 2014, 14, 1073. [CrossRef] [PubMed]

63. Tural, U.; Coşkun, B.; Onder, E.; Corapçioglu, A.; Yildiz, M.; Kesepara, C. Psychological consequences of the 1999 earthquake in Turkey. J. Trauma. Stress 2004, 17, 451-459. [CrossRef] [PubMed]

64. Wang, B.; Ni, C.; Chen, J.; Liu, X.; Wang, A.; Shao, Z. Posttraumatic stress disorder 1 month after 2008 earthquake in China: Wenchuan earthquake survey. Psychiatry Res. 2011, 187, 392-396. [CrossRef] [PubMed]

65. Wang, W.; Fu, W.; Wu, J.; Ma, X.-C.; Sun, X.-L.; Huang, Y. Prevalence of PTSD and depression among junior middle school students in a rural town far from the epicenter of the Wenchuan earthquake in China. PLoS ONE 2012, 7, e41665. [CrossRef] [PubMed]

66. Wen, J.; Shi, Y.-K.; Li, Y.-P.; Yuan, P.; Wang, F. Quality of life, physical diseases, and psychological impairment among survivors 3 years after Wenchuan earthquake: A population based survey. PLoS ONE 2012, 7, e43081. [CrossRef] [PubMed]

67. Xu, J.; Song, X. A cross-sectional study among survivors of the 2008 Sichuan earthquake: Prevalence and risk factors of posttraumatic stress disorder. Gen. Hosp. Psychiatry 2011, 33, 386-392. [CrossRef] [PubMed]

68. Zhang, L.-P.; Zhao, Q.; Luo, Z.-C.; Lei, Y.-X.; Wang, Y.; Wang, P.-X. Prevalence and risk factors of posttraumatic stress disorder among survivors five years after the "Wenchuan" earthquake in China. Health Qual. Life Outcomes 2015, 13, 75. [CrossRef] [PubMed]

69. Zhang, Y.; Ho, S.M.Y. Risk factors of posttraumatic stress disorder among survivors after the 512 Wenchuan earthquake in China. PLoS ONE 2011, 6, e22371. [CrossRef] [PubMed]

70. Zhang, Z.; Shi, Z.; Wang, L.; Liu, M. Post-traumatic stress disorder, anxiety and depression among the elderly: A survey of the hard-hit areas a year after the Wenchuan earthquake. Stress Health 2012, 28, 61-68. [CrossRef] [PubMed]

71. Zhang, Z.; Wang, W.; Shi, Z.; Wang, L.; Zhang, J. Mental health problems among the survivors in the hard-hit areas of the Yushu earthquake. PLoS ONE 2012, 7, e46449. [CrossRef] [PubMed]

72. Zhou, X.; Kang, L.; Sun, X.; Song, H.; Mao, W.; Huang, X. Prevalence and risk factors of post-traumatic stress disorder among adult survivors six months after the Wenchuan earthquake. Compr. Psychiatry 2013, 54, 493-499. [CrossRef] [PubMed]

73. WHO. Determinants of Mental and Behavioural Disorders. 2016. Available online: http://www.who.int/ whr/2001/chapter2/en/index7.html (accessed on 18 July 2016).

74. Korol, M.; Green, B.L.; Gleser, G.C. Children's responses to a nuclear waste disaster: PTSD symptoms and outcome prediction. J. Am. Acad. Child Adolesc. Psychiatry 1999, 38, 368-375. [CrossRef] [PubMed]

75. Galea, S.; Tracy, M.; Norris, F.; Coffey, S.F. Financial and social circumstances and the incidence and course of PTSD in Mississippi during the first two years after Hurricane Katrina. J. Trauma. Stress 2008, 21, 357-368. [CrossRef] [PubMed]

(C) 2017 by the authors. Licensee MDPI, Basel, Switzerland. This article is an open access article distributed under the terms and conditions of the Creative Commons Attribution (CC BY) license (http://creativecommons.org/licenses/by/4.0/). 